\title{
Growth and welfare of submerged Atlantic salmon under continuous lighting
}

\author{
M. Sievers ${ }^{1,2,3, *}$, Ø. Korsøen ${ }^{1}$, T. Dempster ${ }^{1,2}$, P. G. Fjelldal ${ }^{1}$, T. Kristiansen ${ }^{1}$, \\ O. Folkedal ${ }^{1}$, F. Oppedal ${ }^{1}$ \\ ${ }^{1}$ Institute of Marine Research, 5984 Matredal, Norway \\ ${ }^{2}$ School of BioSciences, The University of Melbourne, Parkville, Victoria 3010, Australia \\ ${ }^{3}$ Australian Rivers Institute - Coast \& Estuaries, School of Environment and Science, Griffith University, Gold Coast, \\ Queensland 4222, Australia
}

\begin{abstract}
Although surface-based cages dominate the marine finfish aquaculture industry, production issues that arise at the surface such as poor environmental conditions and the presence of parasites has spurred interest in submerging cages. However, submerged culture is not without its own issues; for example, the adverse effects on fish buoyancy levels can alter swimming speeds and cause tilted swimming at night time, leading to reduced growth rates and vertebral deformities. The use of continuous artificial lighting is common practice in surface-based salmon farming to inhibit maturation. Its implementation can also increase swimming speeds at night, and, if used in submerged cages, may reduce the incidence of tilted swimming. Here we compared submerged (below $10 \mathrm{~m}$ ) and surface culture of Atlantic salmon Salmo salar for $42 \mathrm{~d}$ under continuous lighting. The use of continuous lightning during submergence of large $(3.4 \mathrm{~kg})$ Atlantic salmon increased swimming speeds, reduced tilted swimming, and spinal deformities did not arise. Submerged culture also decreased infestation by attached sea lice stages by $72 \%$, from 4.4 to 1.2 lice per fish. However, specific growth rates of submerged fish were $30 \%$ lower than those of surfacereared fish. Developments in engineering and technologies that allow salmon to refill their swim bladders during submergence show promise in eliminating welfare and growth problems. Robust scientific experiments at full commercial scale of cages and operating systems that consider both production and welfare outcomes are critical to the successful development of submerged farming.
\end{abstract}

KEY WORDS: Aquaculture $\cdot$ Lepeophtheirus salmonis $\cdot$ Parasite control $\cdot$ Salmo salar $\cdot$ Sea lice Mariculture

\section{INTRODUCTION}

Finfish aquaculture is expanding globally, with global protein production from aquaculture surpassing cattle farming (Ottinger et al. 2016). The most cultured fish in the sea, Atlantic salmon Salmo salar, is now worth over US\$ 14 billion $\mathrm{yr}^{-1}$ (FAO 2016). However, the salmon industry suffers from a range of welfare, social and environmental issues, many of which are a direct result of the surface-based nature of current culture methods. For example, extreme weather

*Corresponding author: m.sievers@griffith.edu.au and waves, high temperatures and algal and jellyfish blooms are often more prevalent at the surface within production areas (Dempster et al. 2009). Sea lice, often regarded as the greatest threat for the sustainability, growth and social perception of the salmon industry where wild salmonids are present in the ecosystem, also congregate in surface layers (Heuch et al. 1995, Costello 2006).

Rearing salmon in submerged cages could alleviate the extent or severity of many of these problems, and submerged culture has been successful for Pacific

(C) The authors 2018. Open Access under Creative Commons by Attribution Licence. Use, distribution and reproduction are unrestricted. Authors and original publication must be credited. 
threadfin Polydactylus sexfilis (Ryan 2004), cobia Rachycentron canadum (Rapp et al. 2007) and Atlantic cod Gadus morhua and haddock Melanogrammus aeglefinus (Chambers \& Howell 2006). Deeper environments are generally more stable and are less favoured by monoxenous ectoparasites common to marine aquaculture (e.g. Wright et al. 2015). The adoption of submerged cages also unlocks new areas for production where surface-based sea-cage technologies are inappropriate due to surface wind and waves, or by other constraints such as space conflicts with other coastal users (Sanchez-Jerez et al. 2016).

Despite these potential advantages, salmon are cultured solely in cages open to the surface, and robust, full-scale experiments assessing the suitability and efficacy of submerged culture are scarce. Consequently, a range of biological and technical challenges associated with submerged farming remain unresolved (see Chambers \& Howell 2006, Dempster et al. 2008, Korsøen et al. 2012b, 2013). The main biological challenge for the submerged culture of the physostomous salmon is the need for surface access so fish can fill their swim bladder and maintain buoyancy (Smith 1982). When surface access is deprived, as a behavioural compensation, fish maintain swimming speeds around 1.3-1.6 times faster than speeds prior to submergence and to those of control fish (Dempster et al. 2008, 2009, Korsøen et al. 2009, 2012a). Without access to air, swimming angle increases with duration of submergence (Korsøen et al. 2009), as tilted swimming with a positive angle of attack (i.e. head up, tail down) provides lift (Webb 1993). Long-term tilted swimming is problematic for salmon as it gradually leads to exhaustion and loads the muscles in the tail region to such a degree that some vertebrae become compressed (i.e. lordosis; Fosseidengen et al. 1982, Ablett et al. 1989).

Short-term submergence for days to weeks appears to have relatively little effect on growth rates and condition (Dempster et al. 2008, 2009). However, several longer-term experiments ( $>40 \mathrm{~d}$ ) have shown that salmonids grow poorly in submerged cages, whereby long-term submerged fish fed less efficiently, had lower growth, reduced feed utilization, and suffered minor fin and snout erosion compared to surface-reared fish (Korsøen et al. 2009, 2012a). Given vertebral and growth issues, Korsøen et al. (2012a) argued that long-term submergence (>2 wk) below $10 \mathrm{~m}$ is not acceptable in terms of welfare and performance of farmed salmon.

The use of continuous lighting may alleviate some of these issues. For example, Korsøen et al. (2012a) showed that shallow, short submergences with con- stant underwater illumination resulted in a diurnal swimming depth pattern similar to illuminated control fish, resulting in comparable growth rates and no evident welfare issues. Similarly, shallow submerged salmon exposed to artificial light during summer for 3 wk exhibited no negative effects (Dempster et al. 2009), and the use of subsurface artificial lightning allows fish to naturally school at night (Oppedal et al. 2001, Juell \& Fosseidengen 2004, Hansen et al. 2017) which may help reduce the magnitude of tilted swimming observed under dark conditions, alleviating the associated welfare implications. The use of artificial light to inhibit sexual maturation and improve growth is common practice in salmon aquaculture (Taranger et al. 2010, Hansen et al. 2017). More recently, artificial light has been used to attract salmon deeper and further away from harmful organisms which often congregate at the surface (Frenzl et al. 2014, Wright et al. 2015).

Following the experimental design of Korsøen et al. (2009), we investigated whether continuous light would alleviate the growth and welfare challenges of long-term submergence they observed. Moreover, since this previous work, salmon lice numbers in this study area have significantly increased, allowing us to quantify the effect of submergence on salmon lice infestation.

\section{MATERIALS AND METHODS}

\section{Location and experimental design}

The experiment was conducted at the Cage Environmental Laboratory at the Institute of Marine Research field station, Solheim, in Masfjorden, western Norway $\left(60^{\circ} \mathrm{N}\right)$. Six cages of $2000 \mathrm{~m}^{3}$ volume were used: 3 submerged and 3 surface controls. The 3 control cages were of a standard type $(12 \mathrm{~m} \times 12 \mathrm{~m} \times 14 \mathrm{~m}$ deep). The 3 submerged cages of standard type were $24 \mathrm{~m}$ deep, with a roof of black netting (same material as cage sides and bottom) sewn into the cage net at $10 \mathrm{~m}$ depth giving both treatments the same effective volume. Submerged and control cages were interspersed at the farm to ensure that fine-scale environmental differences did not contribute to treatment effects. The experiment lasted for $48 \mathrm{~d}$, with $1 \mathrm{~d}$ before submergence (experimental Day 1), 42 d of submergence (Days 2-43) and $3 \mathrm{~d}$ post-submergence (Days 44-46) with all cages at the surface. Fish in the control cages had access to the surface throughout. Submergence began at 10:00 h on 17 February 2014 and ended at 10:00 h on 31 March 2014. Submergence 
of cages took approximately $20 \mathrm{~min}$, and re-surfacing took approximately $60 \mathrm{~min}$ per net.

\section{Artificial lighting}

Continuous, artificial lighting was supplied using lamps (SubLite Integra; www.akvagroup.com) with $400 \mathrm{~W}$ bulbs (Powerstar, HQI-BT 400W/D Colour temperature: 32000 lumen, Osram) placed at 8 and $12 \mathrm{~m}$ in control and submerged cages, respectively. These light positions induce swimming at similar depth intervals at night (Oppedal et al. 2007) which are beyond the variable surface layer, and are a standard management tool in commercial production of Atlantic salmon to reduce the sexual maturation of fish (Oppedal et al. 2006). Given the considerable welfare implications of long-term submergence without artificial light discussed in the 'Introduction', we considered it unethical to include a 'no-light' submerged treatment, instead using artificial lighting on all cages, and comparing and contrasting our results with results from previous submergence trials in the same region without artificial light (Korsøen et al. 2009).

\section{Underwater feeding}

Fish were fed a commercial diet $\left(24 \mathrm{MJ} \mathrm{kg}^{-1}\right.$ gross energy value, Classic 1000, BIOMAR) with 1 meal each day starting at 10:30 h. In the submerged cages, feed was delivered through a $12 \mathrm{~m}$ pipe $(\varnothing=63 \mathrm{~mm})$ with running water, $30 \mathrm{~cm}$ below the roof in the centre of the cage (LiftUp). In order to obtain a similar underwater distribution of feed in the control cages, pellets were air blown to the cage and introduced through a large pipe $(\varnothing=40 \mathrm{~cm})$ at $1.5 \mathrm{~m}$ depth in the centre of the cage. Underwater cameras were used by the same operator every day to observe feeding activity and uneaten pellets. The feeding rate was reduced by $50 \%$ when uneaten pellets were observed below the fish, and stopped when pellets were again observed below the fish.

\section{Environmental variables}

A vertically profiling conductivity-temperaturedepth profiler (CTD; SD204, SAIV, www.saivas.no) connected to an automatic winch (HF5000, Belitronics) was used to determine salinity, temperature and oxygen levels from 0 to $25 \mathrm{~m}$ depth throughout the experimental period. One profile was taken every $30 \mathrm{~min}$.

\section{Experimental fish}

Atlantic salmon (Aquagen strain, $\mathrm{n}=5242$ ) with a mean weight of $3.37 \mathrm{~kg}$ and length $62 \mathrm{~cm}$ were randomly distributed among the 6 experimental cages using a well-boat (823-916 fish cage $\left.{ }^{-1}\right)$. A subset of these fish $\left(\mathrm{n}=60 \mathrm{cage}^{-1}\right)$ were netted, anaesthetized with MS 222, measured for weight and fork length, tagged with T-bar anchor tags (Hallprint) and randomly distributed into each cage. Based on these tagged fish, there was no difference in initial length $\left(F_{1,4}=0.0, \mathrm{p}=0.99\right)$, weight $\left(F_{1,4}=0.1, \mathrm{p}=0.8\right)$ or Fulton's $K\left(100 \times\right.$ weight/length $\left.{ }^{3} ; F_{1,4}=0.6, \mathrm{p}=0.5\right)$ between the control and submerged cages.

\section{Vertical distribution in the cages}

The vertical distribution of fish within cages was observed using a PC-based echo integration system (Lindem Data Acquisition) connected to upwardfacing transducers with a $42^{\circ}$ acoustic beam angle. Transducers were positioned at 17 and $27 \mathrm{~m}$ depth under the mid-points of control and submerged cages, respectively. Full details of the system are given in Bjordal et al. (1993) and a detailed description of parameter calculations in Oppedal et al. (2007). Echo intensity, which is directly proportional to fish density, was recorded at $0.5 \mathrm{~m}$ depth intervals from 0.5 to $14 \mathrm{~m}$ in each of the 28 layers in control cages and submerged cages during non-submerged days and 26 layers in submerged cages during submergence. Total acoustic backscatter values per minute were low-pass filtered, where 0 values and those outside of the mean $\pm 2 \mathrm{SD}$ were removed to reflect realistic values (Bui et al. 2013). Using these data, we calculated the average total target strengths over all depths per day per cage to provide an estimate of swim bladder fullness.

\section{Swimming behaviour}

Swimming behaviour was monitored in each cage with underwater cameras positioned in the centre, and vertical reference lines hung $2 \mathrm{~m}$ in front of the cameras. Cameras were remotely controlled by winches and positioned within the depth layer occupied by most fish during sample time. Five minute video recordings were made in control and submerged cages during the day (at 14:00 h) and night (at 23:00 h). From these, instantaneous swimming speeds were calculated as body lengths per second $\left(\mathrm{BL} \mathrm{s}^{-1}\right)$ by 
using the time taken to pass the vertical reference line from the snout to the tail $\left(\mathrm{n}=30\right.$ random fish cage $\mathrm{e}^{-1}$ time $^{-1}$ ). Swimming tilt angle was estimated from still pictures as the angle between the anterior-posterior axis of the fish and the vertical reference line $(\mathrm{n}=$ 15-30 random fish cage ${ }^{-1}$ time $^{-1}$ ). Throughout the experimental period, swimming speed was recorded 8 times during the day and 5 times at night, and tilt angle was recorded 3 times at night.

\section{Growth and welfare}

At the end of the trial (Day 48), 38-49 of the tagged fish were retrieved from each cage, and measured for fork length, weight, sea lice infestation and snout condition. Snout condition was scored as 2 for significant snout damage, 1 for any sign of skin wear or light damage and 0 if no damage was evident. Specific growth rate and lengthening rate (SGR and LR, respectively, \% $\left.\mathrm{d}^{-1}\right)$ were calculated as $\left(\mathrm{e}^{q}-1\right) \times 100$, where $q=\left[\ln \left(W_{2}\right)-\ln \left(W_{1}\right)\right] \times\left(t_{2}-t_{1}\right)^{-1} \cdot t_{2}$ and $t_{1}$ are the time in days at the end and beginning of the experiment, respectively. $W_{2}$ and $W_{1}$ are the wet body weights or lengths at the end and beginning of the trial, respectively. Fulton's condition factor $(K)$ was calculated as $W \times L^{-3} \times 100$, where $W$ is the wet weight $(\mathrm{g})$, and $L$ is the fork length $(\mathrm{cm})$.

At harvest, 10 randomly chosen tagged fish from each treatment were dissected to remove their vertebral columns which were radiographed (Sambraus et al. 2014). Vertebral cranial-caudal length, and dorsoventral diameter of single vertebrae were measured in the regions V17-20 (trunk) and V40-43 (tail) using image analysis software (Image-Pro Plus, version 4.0, Media Cybernetics).

At harvest, we counted all salmon lice on fish. Stages were differentiated into attached (copepodid and chalimi) and mobile (pre-adult and adult) stages. Given the length of the trial, prevailing temperature and lice development rates, we only included attached lice in analyses since most mobile lice would have been on fish prior to the trial commencing.

\section{Statistical analyses}

Initial differences in length and weight of control and treatment fish, and final differences in the SGRs, condition indices, the number of attached lice per fish at the end of the trial and the length to height (dorso-ventral diameter) ratio of each vertebral region (i.e. V1720 and V40-43) were tested using 1-way ANOVAs.
Swimming speeds during the day and night, and tilt angles for the submerged and control treatments were compared using repeated measures ANOVAs. Normality and homogeneity of variances were assessed before all analyses using $\mathrm{Q}-\mathrm{Q}$ and Levene's tests, respectively. Transformations (specified in tables and figures) were performed to meet statistical assumptions when appropriate. All analyses were performed in $\mathrm{R}$ 3.2.2 (R Development Core Team 2015).

\section{RESULTS}

\section{Environmental conditions}

The fjord environment was normal for the season with an upper $2-5 \mathrm{~m}$ of the water column typically cooler (down to $2.7^{\circ} \mathrm{C}$ ) and more brackish (down to $0 \mathrm{ppt}$ ) than the full saline (30-34 ppt) water below the halocline (Fig. 1). Temperatures at the typical preferred swimming depths of the fish (i.e. warmest water available up to approximately $16^{\circ} \mathrm{C}$; Oppedal et al. 2011) decreased from 8 to $5^{\circ} \mathrm{C}$ over the experimental period, indicating that preferred temperatures were available for both the control and the submerged fish, and oxygen levels were consistently above known thresholds for normal growth and welfare performance Atlantic salmon (> $84 \%$ saturation; Remen et al. 2016).

\section{Swim bladder fullness and swim depth}

Echosounder output showed rapid reductions in signal strength within $1 \mathrm{wk}$ of submergence (Fig. 2), indicating a reduction in the fullness of swim bladders. Signal strength then continually decreased and plateaued at very low levels, and after approximately $30 \mathrm{~d}$, signals were almost non-existent, indicating that the swim bladders of the submerged salmon were almost empty. Following re-surfacing, signal strength increased immediately to similar levels in all cages (Fig. 2). Generally, fish schooled around the depth of the light source at night (data not shown). During the day, surface fish swam closer to surface, but avoided the colder surface layer, while submerged fish swam closer to the net roof.

\section{Swimming behaviour}

Swimming speeds remained largely consistent for control fish throughout the experimental period, averaging (mean $\pm \mathrm{SE}$ ) $0.67 \pm 0.03 \mathrm{BL} \mathrm{s}^{-1}$ during the 


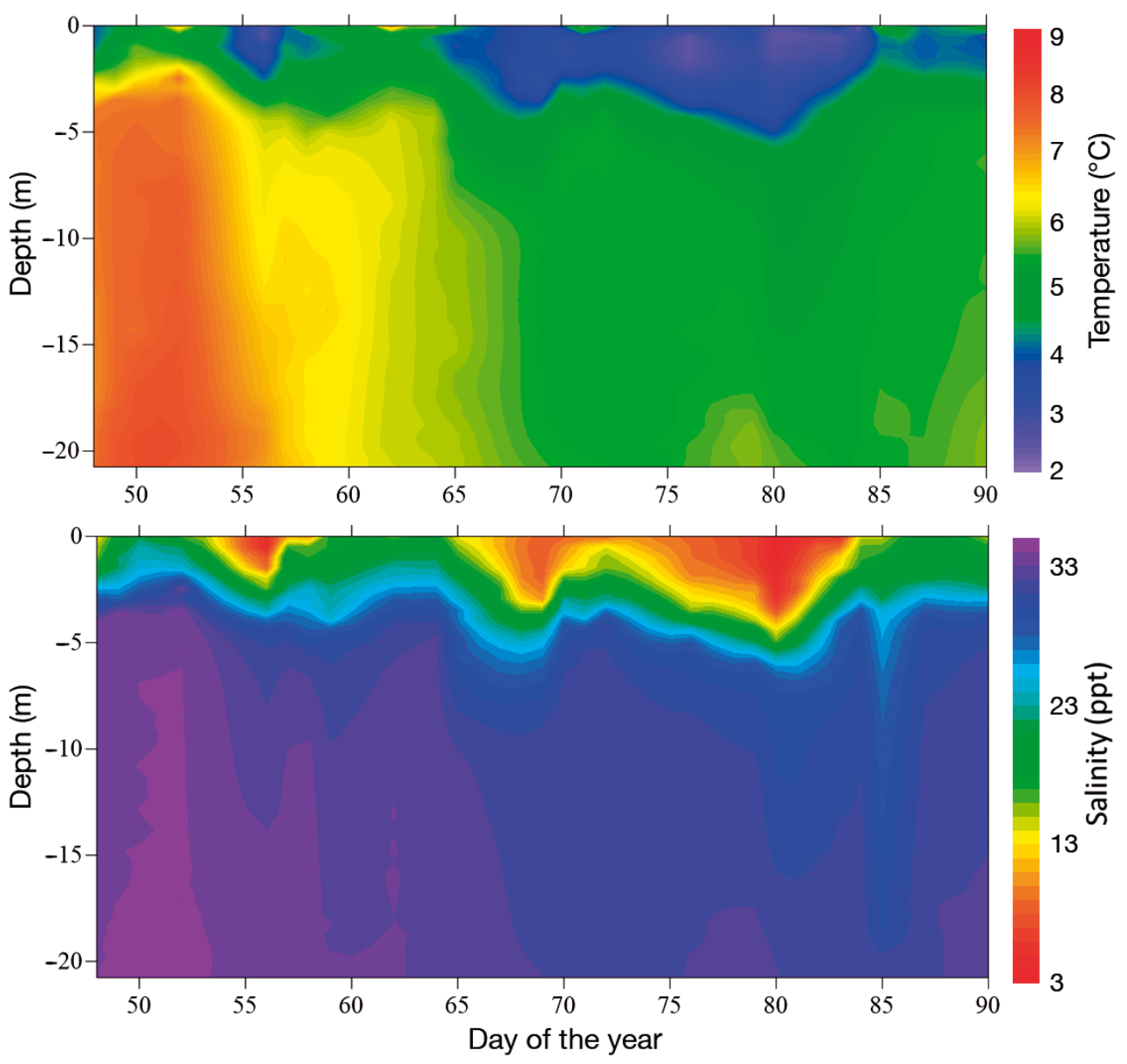

Fig. 1. Temperature and salinity profiles for the surface $25 \mathrm{~m}$ from the beginning to the end of the submergence period (42 $\mathrm{d}$ )

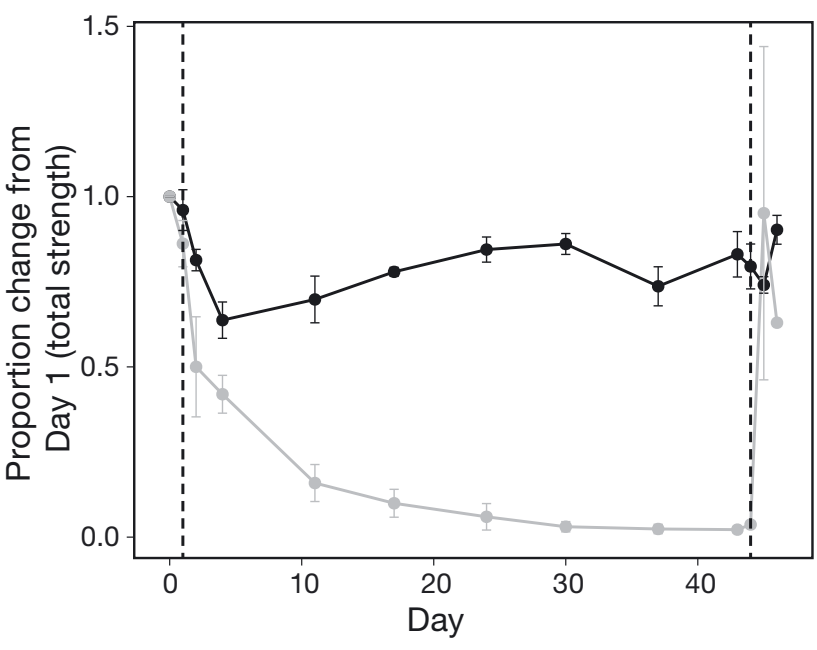

Fig. 2. Proportion change in echo strength for the control (black) and submerged (grey) salmon cages. Data are means $\pm \mathrm{SE}$ recorded 13 times throughout the experimental period. Vertical dashed lines represent submergence and resurfacing of submerged cages; $\mathrm{n}=3$, except for the last time point for submerged cages when $\mathrm{n}=1$ due to hardware error day and $0.63 \pm 0.04 \mathrm{BL} \mathrm{s}^{-1}$ during the night (Fig. 3). Swimming speeds initially increased in submerged cages and then plateaued at a higher level than control fish at $0.78 \pm 0.04 \mathrm{BL} \mathrm{s}^{-1}$ (1.16 times higher) during the day and $0.81 \pm 0.02 \mathrm{BL} \mathrm{s}^{-1}$ (1.29 times higher) during the night (Table 1, Fig. 3). At the final recorded time, on Day 36, swimming speeds were 1.64 and 1.28 times faster in submerged fish during the day and at night, respectfully. The swimming angle of control fish did not change throughout the experiment, with a mean angle of $-0.75 \pm 0.31^{\circ}$. The swimming angle of submerged fish increased as submergence time increased, reaching $16.3 \pm 4.3^{\circ}$ after $36 \mathrm{~d}$ of submergence (Table 1, Fig. 3).

\section{Growth and welfare}

Fish in submerged cages grew more slowly in terms of both length and weight, but had comparable Fulton's $K$ condition factor (Table 2, Fig. 4). SGR (\% 

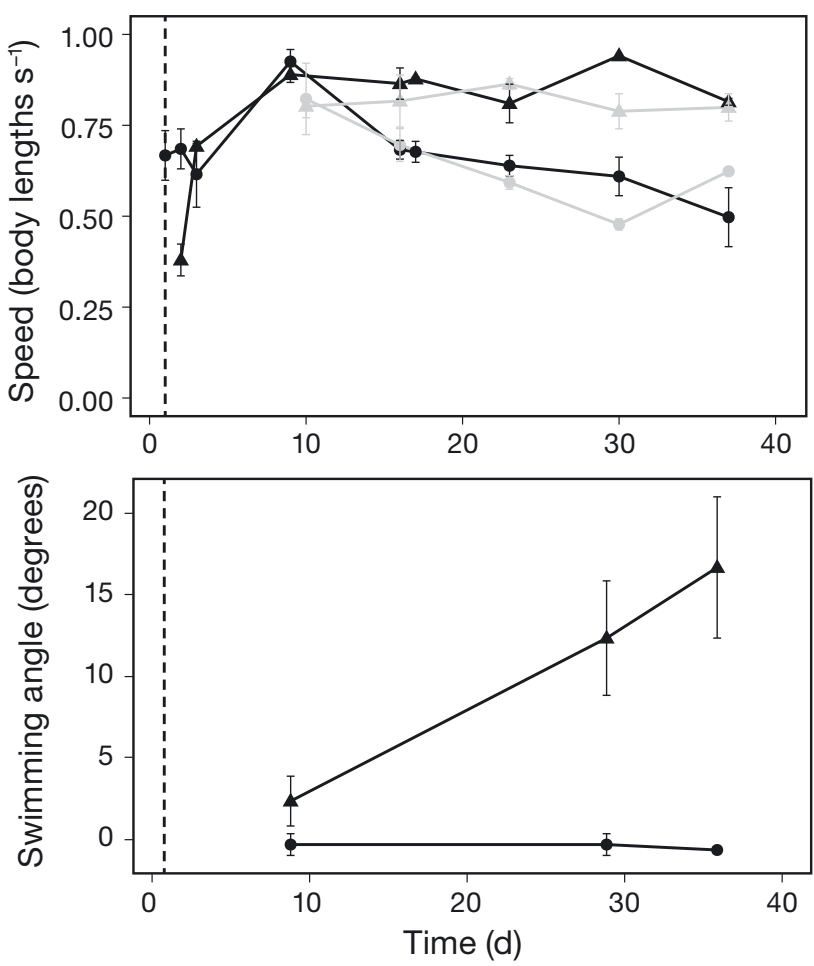

Fig. 3. Swimming behaviour of salmon reared in submerged (triangles) and surface (circles) cages for $42 \mathrm{~d}$ : (a) swimming speed in body lengths $\mathrm{s}^{-1}$ ( $\mathrm{n}=3$ cages, 30 fish cage ${ }^{-1}$ ) during the day (black) and at night (grey), and (b) swimming angle, i.e. the angle between the anterior-posterior axis of the fish

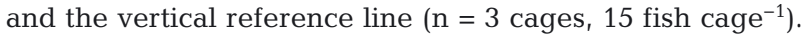
Vertical dashed lines: time of submergence of submerged cages. Data are means $\pm \mathrm{SE}$

$\left.\mathrm{d}^{-1}\right)$ and LR $\left(\% \mathrm{~d}^{-1}\right)$ of surface-reared fish were 30 and $19 \%$ higher, respectively, than those reared in submerged cages (Fig. 4). Although fish in submerged cages had a higher average snout condition, there was high variability among cages, so differences were not statistically significant (Table 2, Fig. 4). The height to length ratio of vertebrae in both regions were the same for submerged and control fish (Table 2, Fig. 4).

Submerged fish had $72 \%$ fewer attached sea lice, from 4.4 to 1.2 per fish, than control fish $\left(F_{1,4}=15.6\right.$, $\mathrm{p}=0.02 ;$ Fig. 4 ).

\section{DISCUSSION}

We demonstrate that the use of standard, continuous artificial lighting during deep, long-term submergence of large Atlantic salmon during winter resulted in night-time swimming speeds that reduced tilted swimming and the associated spinal deformities reported by Korsøen et al. (2009). Salmon
Table 1. Output from repeated-measures ANOVA of linear models with treatment (control or submerged salmon cages) fitted as fixed effects. Significant $p$-values $(p<0.05)$ are in bold

\begin{tabular}{|lcccc}
\hline & $\mathrm{df}$ & $\mathrm{MS}$ & $F$ & $\mathrm{p}$ \\
\hline $\begin{array}{l}\text { Speed (day) } \\
\text { Between subjects }\end{array}$ & & & & \\
$\quad$ Treatment & 1 & 0.43 & 35.5 & $\mathbf{0 . 0 0 4}$ \\
$\quad$ Residuals & 4 & 0.01 & & \\
$\quad$ Within subjects & & & & \\
$\quad$ Treatment & 1 & 0.04 & 2.12 & 0.153 \\
$\quad$ Residuals & 43 & 0.02 & & \\
Speed (night) & & & & \\
$\quad$ Between subjects & & & & \\
$\quad$ Treatment & 1 & 0.27 & 20.4 & $\mathbf{0 . 0 1 1}$ \\
$\quad$ Residuals & 4 & 0.01 & & \\
$\quad$ Within subjects & & & & \\
$\quad$ Treatment & 1 & 0.002 & 0.32 & 0.578 \\
Residuals & 19 & 0.006 & & \\
Angle (night) & & & & \\
Between subjects & & & & \\
$\quad$ Treatment & 1 & 6.35 & 21.1 & $\mathbf{0 . 0 1 0}$ \\
$\quad$ Residuals & 4 & 0.3 & & \\
Within subjects & & & & \\
$\quad$ Treatment & 1 & 0.6 & 0.83 & 0.387 \\
$\quad$ Residuals & 9 & 0.73 & &
\end{tabular}

${ }^{\text {a }}$ Measuresments were log transformed to meet the assumptions of normality and homogeneity of variance

in control cages had 3.6 times more salmon lice than fish in submerged cages. However, while overall fish body and snout condition did not differ between submerged and control cages, growth in submerged cages was considerably reduced. Unlike some previous attempts to examine the effects of submerged culture (e.g. Osland et al. 2001, Dempster et al. 2008), no confounding effects were thought to be present as a result of environmental variables such as temperature, salinity or oxygen, or light availability, as they were similar among the treatments.

\section{Negative buoyancy and behavioural adaptation under continuous lighting}

Buoyancy regulation in most teleosts is accomplished by swim bladder volume regulation (Horn 1975). Echosounder data suggest that salmon in submerged cages empty their swim bladder gradually over approximately 3 wk (Dempster et al. 2009, Korsøen et al. 2009). The reduction in echosounder signal strength for submerged cages observed here showed that fish rapidly emptied their swim bladder after just a few days, quicker than observed in similar 
Table 2. Output from ANOVA of linear models with treatment (control or submerged salmon cages) fitted as fixed effects. Significant $p$-values $(p<0.05)$ are in bold. SGR: specific growth rate, LR: lengthening rate

\begin{tabular}{|lcccc|}
\hline & $\mathrm{df}$ & $\mathrm{MS}$ & $F$ & $\mathrm{p}$ \\
\hline SGR & & & & \\
$\quad$ Treatment & 1 & 0.025 & 7.96 & $\mathbf{0 . 0 4 7}$ \\
$\quad$ Residuals & 4 & 0.003 & & \\
LR & & & & \\
$\quad$ Treatment & 1 & 0.001 & 64 & $\mathbf{0 . 0 0 1}$ \\
$\quad$ Residuals & 4 & $<0.0001$ & & \\
Fulton's $K$ & & & & \\
$\quad$ Treatment & 1 & 0.00027 & 3.2 & 0.148 \\
$\quad$ Residuals & 4 & $<0.0001$ & & \\
Snout condition & & & & \\
$\quad$ Treatment & 1 & 0.101 & 2.21 & 0.212 \\
$\quad$ Residuals & 4 & 0.046 & & \\
Vertebral ratio trunk & & & & \\
$\quad$ Treatment & 1 & $<0.0001$ & 0.008 & 0.934 \\
$\quad$ Residuals & 4 & $<0.0001$ & & \\
Vertebral ratio tail & & & & \\
$\quad$ Treatment & 1 & $<0.0001$ & 0.242 & 0.649 \\
$\quad$ Residuals & 4 & 0.0001 & & \\
Sea lice & & & & \\
$\quad$ Treatment & 1 & 15.6 & 15.5 & $\mathbf{0 . 0 1 7}$ \\
Residuals & 4 & 0.99 & & \\
$\quad$ & & & & \\
\hline
\end{tabular}

studies (e.g. Dempster et al. 2009, Korsøen et al. 2009). Like Dempster et al. (2009), we observed stable (but faster) swimming speeds of salmon in the submerged cages over time despite the steady decline of swim bladder volumes. Since fish size and lipid content are positively correlated (Solberg et al. 2003), large fish like those used here are more buoyant than smaller fish that swim faster with time submerged. High-resolution, individual depth-based tracking of fish during submergence is needed to elucidate whether fine-scale compensatory behaviour occurs, such as whether individual fish slowly spiral downwards within the cage over time within their preferred depth range before swimming upward to the top of the depth range.

Negative buoyancy from an emptying swimming bladder triggered a set of identifiable compensatory behavioural responses, such that submerged fish swam faster and at a greater tilt angle than surfacereared fish. While the surface fish swam with the head pointed slightly downwards (angle: $-0.75^{\circ}$ ), indicating neutral or slightly positive buoyancy, the swimming tilt angle of submerged fish gradually increased with the duration of the submergence (up to $16.3^{\circ}$ ), indicating increasing negative buoyancy.
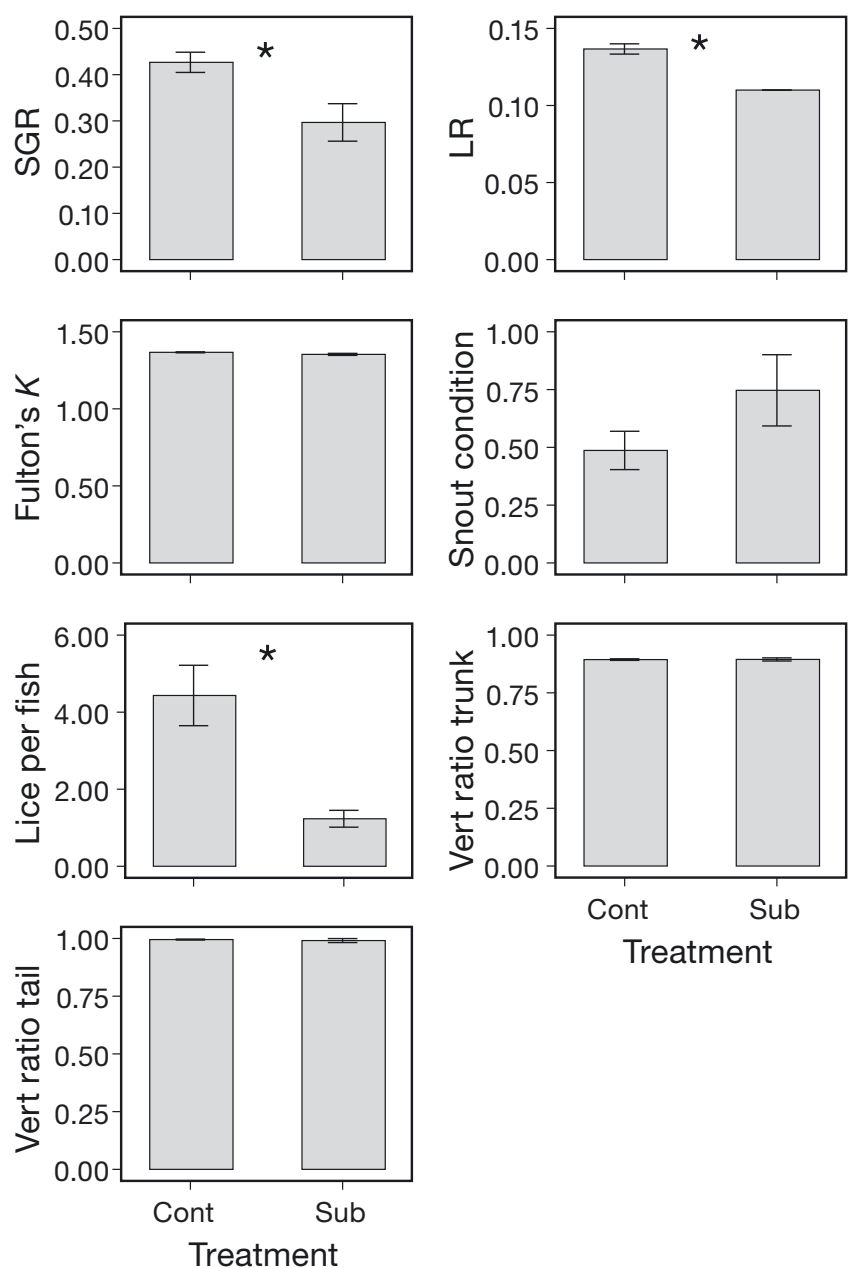

Treatment

Fig. 4. Mean $( \pm \mathrm{SE})$ specific growth rate $\left(\mathrm{SGR}_{i} \% \mathrm{~d}^{-1}\right)$, lengthening rate $\left(\mathrm{LR}_{i} \% \mathrm{~d}^{-1}\right)$, Fulton's $K$ condition factor, snout condition (where 2 = significant snout damage, $1=$ any sign of skin wear or light damage and $0=$ no damage), the number of immobile lice per fish and the vertebral ratio for the trunk and tail regions for fish reared in surface control cages (Cont) and submerged cages (Sub). ${ }^{*}$ Significance

$(\alpha=0.05)$ between submerged and surface treatments

The addition of continuous, artificial light increased swimming speeds at night, which reduced tilted swimming compared to the $36^{\circ}$ observed by Korsøen et al. (2009). Given the unacceptable welfare issues associated with submerged culture without artificial lighting, we did not incorporate a 'no-light' treatment group within our study. Therefore, there is potential for other factors to influence rates of titled swimming. However, given the similarities between this and the study by Korsøen et al. (2009), such as trial location, time of year and fish size, we are confident in concluding that artificial light was the primary driver of faster swimming speeds and reduced tilt swimming. Dempster et al. (2009) also observed greater school- 
ing density in surface-reared fish at night compared to submerged fish under artificial lighting regimes.

This reduction in tilted swimming eliminated the vertebral overload and subsequent deformities observed by Korsøen et al. (2009), and the vertebral ratios observed here were well within normal levels (Fjelldal et al. 2009). However, this is still an area of some concern given the considerable differences between submerged and surface-reared fish even under continuous lighting. We echo the sentiments of Korsøen et al. (2009) insofar that we need to test whether faster-growing post-smolts are more susceptible to developing vertebral deformities during periods of submergence compared to larger and slowergrowing fish, as used in the present experiment. Increased swimming speed has a positive effect on bone mineralisation in Atlantic salmon post-smolts (Totland et al. 2011), and so the use of continuous light may improve bone mineralisation in submerged salmon, reducing the impacts of tilted swimming on the vertebral column.

\section{Submergence-induced growth reductions}

Growth rates were comparable to studies on similarly sized fish at the same time of year (e.g. Hansen et al. 2017), and above predictions provided from feed suppliers (F. Oppedal pers. obs.). However, in contrast to earlier research on smaller salmon $(500 \mathrm{~g})$ over shorter submergence durations ( $3 \mathrm{wk}_{\text {; }}$ Dempster et al. 2009), submerged fish did not grow as long or as heavy as surface-reared fish after $42 \mathrm{~d}$ of submergence. However, growth reductions recorded in our study are lower than in other experiments with similar sized fish and submergence durations (53\%; Korsøen et al. 2009), possibly due to continuous lighting reducing the energetic costs associated with faster swimming and tilting. Growth rate has been regarded as a solid, long-term operational welfare measure (Huntingford et al. 2006). Although observed growth reductions did not affect the condition of the fish, observed declines in growth rates of submerged fish are likely unacceptable from an industry perspective and are an obvious welfare breach.

Although fish in submerged cages had a higher average snout score, there was very high variability among cages and no overall difference to control cages was evident. Previous work has identified that forced submergence and a lack of access to air to fill swim bladders can cause fish to interact with the roof of the cage, resulting in physical damage to the snout, fins or skin (Korsøen et al. 2009). Future work on the potential for submerged culture should thus document the welfare of fish using recently published welfare indices (e.g. the 'Salmon Welfare Index Model', SWIM; Stien et al. 2013).

Sea lice are more abundant in surface waters at salmon farms (Oppedal et al. 2017), and rearing salmon in submerged cages reduced the number of new lice infections dramatically. A $72 \%$ reduction in the number of lice per fish is economically, socially and environmentally important. Although lice levels during the experiment were not particularly high, if relative differences (i.e. $72 \%$ difference) existed at high levels of infestation, outcomes would be even more substantial. Still, Norway sets strict maximum lice levels before treatments are applied (i.e. 0.5 mature lice per fish; Norwegian Ministry of Trade, Industry and Fisheries 2018), so reductions observed here are commercially relevant. In addition, such reductions would undoubtedly lead to long-term welfare benefits from reduced infection and less frequent de-lousing procedures. This is the first documented evidence that submerged cages reduce lice loads, and our results reflect the positive effects of other depthbased strategies to prevent salmon lice infections, such as skirts, snorkels, deep feeding and deep lights (Frenzl et al. 2014, Stien et al. 2016, 2018, Wright et al. 2017).

\section{CONCLUSIONS AND FUTURE PERSPECTIVES}

Submergence of salmon to shallow depths for 2-3 wk has been demonstrated as a possible farming method under certain environmental conditions without major loss of growth or compromising the welfare of fish (Dempster et al. 2008, 2009). However, longer-term submergence can lead to reduced growth and welfare issues, which must be addressed to enable submergence as an ethically, environmentally and economically viable culture method. The use of continuous artificial lighting during submergence reduced some of these issues and appears a useful tool to be used alongside other mitigation measures. Further developments in engineering and technologies that allow fish to refill their swim bladders while in submerged cages (e.g. air domes or pockets; Korsøen et al. 2012b) show promise in eliminating production and welfare issues associated with submerged farming and levering out the advantage in reduced salmon lice loads it can deliver. Alternatively, short-term re-surfacing of submerged cages periodically to allow swim bladder re-filling may alleviate growth and welfare issues. 
Our findings add to the small but growing body of literature suggesting that the outcomes of submergence differ depending on fish size and the ambient environmental conditions, which vary considerably among farms, among times and with depth (Johansson et al. 2006, 2007). Real-time hydrographic information would enable informed decisions regarding submergence to be made at the level of the individual salmon farm. Submerged culture of salmonids is a promising development, but requires significant effort to develop appropriate cages that consider not only production efficiencies but the welfare of the culture species, both of which require robust scientific testing at full commercial scales.

Acknowledgements. We thank Jan Olav Fosse, Kristian Dale, Tone Vågseth, Britt Daae, Grethe Thorsheim, Lars Helge Stien, Grigory Merkin and Jan Erik Fosseidengen for skilled support, and Einar Holmefjord (LiftUp AS) for the underwater feeding system. Funding was provided by the Norwegian Research Council Centre for Research Innovation in Aquaculture Technology (CREATE, 841005) through the subproject SMARTSUB and finalized within project Future Welfare (267800). The work was conducted in accordance with the laws and regulations controlling experiments and procedures on live animals in Norway following the Norwegian Regulation on Animal Experimentation 1996 (Ethics approval 6152).

\section{LITERATURE CITED}

Ablett RF, Marr CR, Roberts JD (1989) Influence of chronic subsurface retention on swimming activity of Atlantic salmon (Salmo salar) in cold temperature conditions. Aquacult Eng 8:1-13

Bjordal $\AA$, Juell JE, Lindem T, Fernö A (1993) Hydroacoustic monitoring and feeding control in cage rearing of Atlantic salmon (Salmo salar L.). In: Reinersten H, Jorgensen L (eds) Fish farming technology. Balkema, Rotterdam, p 203-208

Bui S, Oppedal F, Korsøen ØJ, Sonny D, Dempster T (2013) Group behavioural responses of Atlantic salmon (Salmo salar L.) to light, infrasound and sound stimuli. PLOS ONE 8:e63696

Chambers MD, Howell WH (2006) Preliminary information on cod and haddock production in submerged cages off the coast of New Hampshire, USA. ICES J Mar Sci 63: 385-392

Costello MJ (2006) Ecology of sea lice parasitic on farmed and wild fish. Trends Parasitol 22:475-483

№mpster T, Juell JE, Fosseidengen JE, Fredheim A, Lader P (2008) Behaviour and growth of Atlantic salmon (Salmo salar L.) subjected to short-term submergence in commercial scale sea-cages. Aquaculture 276:103-111

* Dempster T, Korsoen O, Folkedal O, Juell JE, Oppedal F (2009) Submergence of Atlantic salmon (Salmo salar L.) in commercial scale sea-cages: a potential short-term solution to poor surface conditions. Aquaculture 288:254-263

FAO (2016) The state of world fisheries and aquaculture 2016. FAO, Rome
Fjelldal PG, Hansen T, Breck O, Sandvik R, Waagbø R, Berg A, Ørnsrud R (2009) Supplementation of dietary minerals during the early seawater phase increase vertebral strength and reduce the prevalence of vertebral deformities in fast growing under yearling Atlantic salmon (Salmo salar L.) smolt. Aquacult Nutr 15:366-378

Fosseidengen JK, Boge E, Huse I (1982) A survey with rainbow trout and salmon in submersible cages. Norsk Fiskeoppdrett 10:24-25 (in Norwegian)

Frenzl B, Stien LH, Cockerill D, Oppedal F and others (2014) Manipulation of farmed Atlantic salmon swimming behaviour through the adjustment of lighting and feeding regimes as a tool for salmon lice control. Aquaculture 424-425:183-188

*Hansen TJ, Fjelldal PG, Folkedal O, Vågseth T, Oppedal F (2017) Effects of light source and intensity on sexual maturation, growth and swimming behaviour of Atlantic salmon in sea cages. Aquacult Environ Interact 9:193-204

*Heuch PA, Parsons A, Boxaspen K (1995) Diel vertical migration: a possible host-finding mechanism in salmon louse (Lepeophtheirus salmonis) copepodids. Can J Fish Aquat Sci 52:681-689

Horn MH (1975) Swim-bladder state and structure in relation to behavior and mode of life in stromateoid fishes. Fish Bull 73:95-109

Huntingford FA, Adams C, Braithwaite VA, Kadri S, Pottinger TG, Sandøe P, Turnbull JF (2006) Current issues in fish welfare. J Fish Biol 68:332-372

Johansson D, Ruohonen K, Kiessling A, Oppedal F, Stiansen JE, Kelly M, Juell JE (2006) Effect of environmental factors on swimming depth preferences of Atlantic salmon (Salmo salar L.) and temporal and spatial variations in oxygen levels in sea cages at a fjord site. Aquaculture 254:594-605

Johansson D, Juell JE, Oppedal F, Stiansen JE, Ruohonen K (2007) The influence of the pycnocline and cage resistance on current flow, oxygen flux and swimming behaviour of Atlantic salmon (Salmo salar L.) in production cages. Aquaculture 265:271-287

Juell JE, Fosseidengen JE (2004) Use of artificial light to control swimming depth and fish density of Atlantic salmon (Salmo salar) in production cages. Aquaculture 233:269-282

Korsøen ØJ, Dempster T, Fjelldal PG, Oppedal F, Kristiansen TS (2009) Long-term culture of Atlantic salmon (Salmo salar L.) in submerged cages during winter affects behaviour, growth and condition. Aquaculture 296:373-381

Korsøen ØJ, Dempster T, Oppedal F, Kristiansen TS (2012a) Individual variation in swimming depth and growth in Atlantic salmon (Salmo salar L.) subjected to submergence in sea-cages. Aquaculture 334-337:142-151

Korsøen ØJ, Fosseidengen JE, Kristiansen TS, Oppedal F, Bui S, Dempster T (2012b) Atlantic salmon (Salmo salar L.) in a submerged sea-cage adapt rapidly to re-fill their swim bladders in an underwater air filled dome. Aquacult Eng 51:1-6

Korsøen ØJ, Dempster T, Fosseidengen JE, Karlsen Ø, Oppedal F, Stien LH, Kristiansen TS (2013) Towards cod without spawning: artificial continuous light in submerged sea-cages maintains growth and delays sexual maturation for farmed Atlantic cod Gadus morhua. Aquacult Environ Interact 3:245-255

Norwegian Ministry of Trade, Industry and Fisheries (2008) Forskrift om drift av akvakulturanlegg (akvakulturdriftsforskriften), FOR-2008-06-17-822. https://lovdata.no/ 
dokument/SF/forskrift/2008-06-17-822?q=FOR-2008-0617-822

Oppedal F, Juell JE, Tarranger GL, Hansen T (2001) Artificial light and season affects vertical distribution and swimming behaviour of post smolt Atlantic salmon in sea cages. J Fish Biol 58:1570-1584

Oppedal F, Berg A, Olsen RE, Taranger GL, Hansen T (2006) Photoperiod in seawater influence [sic] seasonal growth and chemical composition in autumn sea-transferred Atlantic salmon (Salmo salar L.) given two vaccines. Aquaculture 254:396-410

Oppedal F, Juell JE, Johansson D (2007) Thermo- and photoregulatory swimming behaviour of caged Atlantic salmon: implications for photoperiod management and fish welfare. Aquaculture 265:70-81

Oppedal F, Dempster T, Stien LH (2011) Environmental drivers of Atlantic salmon behaviour in sea-cages. Rev Aquacult 311:1-18

Oppedal F, Samsing F, Dempster T, Wright DW, Bui S, Stien LH (2017) Sea lice infestation levels decrease with deeper 'snorkel' barriers in Atlantic salmon sea-cages. Pest Manag Sci 73:1935-1943

Osland H, Sandvik J, Holm J, Heuch P, Bakke S (2001) Studie av lakseluspåslag og tilvekst hos Atlantisk laks (Salmo salar) i nedsenkede merder. HSF-report, R-NR 4: 01-22. www.nb.no/items/URN:NBN:no-nb_digibok_2009 072901038

Ottinger M, Clauss K, Kuenzer C (2016) Aquaculture: relevance, distribution, impacts and spatial assessments a review. Ocean Coast Manag 119:244-266

R Development Core Team (2015) R: a language and environment for statistical computing. R Foundation for Statistical Computing, Vienna. www.r-project.org

Rapp P, Ramirez WR, Rivera JA, Carlo M, Luciano R (2007) Measurement of organic loading under an open-ocean aquaculture cage, using sediment traps on the bottom. J Appl Ichthyol 23:661-667

Remen M, Sievers M, Torgersen T, Oppedal F (2016) The oxygen threshold for maximal feed intake of Atlantic salmon post-smolts is highly temperature-dependent. Aquaculture 464:582-592

Ryan J (2004) Farming the deep blue. Report to the Irish Sea Fisheries Board and the Irish Marine Institute. www. bim.ie/media/bim/content/downloads/Farming, the, Deep,Blue.pdf

Sambraus F, Glover KA, Hansen T, Fraser TWK, Solberg MF, Fjelldal PG (2014) Vertebra deformities in wild Atlantic salmon caught in the Figgjo River, southwest Nor-

Editorial responsibility: Megan La Peyre,

Baton Rouge, Louisiana, USA way. J Appl Ichthyol 30:777-782

* Sanchez-Jerez P, Karakassis I, Massa F, Fezzardi D and others (2016) Aquaculture's struggle for space: the need for coastal spatial planning and the potential benefits of Allocated Zones for Aquaculture (AZAs) to avoid conflict and promote sustainability. Aquacult Environ Interact 8: 41-54

Smith LS (1982) Introduction to fish physiology. T.F.H. Publications, Hong Kong

* Solberg C, Saugen E, Swenson LP, Bruun L, Isaksson T (2003) Determination of fat in live farmed Atlantic salmon using non invasive NIR techniques. J Sci Food Agric 83:692-696

Stien LH, Bracke MBM, Folkedal O, Nilsson J and others (2013) Salmon Welfare Index Model (SWIM 1.0): a semantic model for overall welfare assessment of caged Atlantic salmon: review of the selected welfare indicators and model presentation. Rev Aquacult 5:33-57

Stien LH, Dempster T, Bui S, Glaropoulos A, Fosseidengen JE, Wright DW, Oppedal F (2016) 'Snorkel' sea lice barrier technology reduces sea lice loads on harvest-sized Atlantic salmon with minimal welfare impacts. Aquaculture 458:29-37

Stien LH, Lind MB, Oppedal F, Wright DW, Seternes T (2018) Skirts on salmon production cages reduced salmon lice infestations without affecting fish welfare. Aquaculture 490:281-287

Taranger GL, Carrillo M, Schulz RW, Fontaine P and others (2010) Control of puberty in farmed fish. Gen Comp Endocrinol 165:483-515

พ Totland GK, Fjelldal PG, Kryvi H, Løkka G and others (2011) Sustained swimming increases the mineral content and osteocyte density of salmon vertebral bone. J Anat 219: 490-501

Webb PW (1993) Is tilting behaviour at low swimming speeds unique to negatively buoyant fish? Observations on steelhead trout, Oncorhynchus mykiss, and bluegill, Lepomis macrochirus. J Fish Biol 43:687-694

Wright DW, Nowak B, Oppedal F, Bridle A, Dempster T (2015) Depth distribution of the amoebic gill disease agent, Neoparamoeba perurans, in salmon sea-cages. Aquacult Environ Interact 7:67-74

*Wright DW, Stien LH, Dempster T, Vågseth T, Nola V, Fosseidengen JE, Oppedal F (2017) 'Snorkel' lice barrier technology reduced two co-occurring parasites, the salmon louse (Lepeophtheirus salmonis) and the amoebic gill disease causing agent (Neoparamoeba perurans), in commercial salmon sea-cages. Prev Vet Med 140:97-105

Submitted: September 3, 2018; Accepted: October 22, 2018 Proofs received from author(s): November 15, 2018 